INSTITUTE OF FORESTRY • BELGRADE

INSTITUT ZA ŠUMARSTVO • BEOGRAD

SUSTAINABLE FORESTRY

COLLECTION 79-80, 2019
ODRŽIVO ŠUMARSTVO

ZBORNIK RADOVA 79-80, 2019

UDK 630*111.86:551.588.6(497.6)

Original scientific paper

\title{
CLIMATE CHARACTERISTICS OF MOUNTAIN BEECH FORESTS BELT (Fagetum montanum illyricum Fuk. et Stef. 1958) ON MANJAČA
}

\author{
Saša EREMIJA ${ }^{l}$, Ljiljana BRA ŠANAC-BOSANAC ${ }^{l}$, \\ Tatjana ĆIRKOVIĆ-MITROVIĆ ${ }^{l}$, Snežana STAJIĆ ${ }^{l}$
}

\begin{abstract}
This paper describes climate characteristics of mountain beech forests belt on Manjača in the southwestern part of the Republic of Srpska, based on climate data from typical meteorological stations for this region (for the period of ten years 1971-1980). Based on specific temperature and precipitation gradients, average values of the most important climate elements for the studied area are determined by extrapolating. Also, annual and monthly values of climate elements that are important for development of vegetation such as: temperature and precipitation regime, climate-geographical characteristics - thermodrome coefficient by Kerner (KP), drought index by De Martonn (Is), Furnije's coefficient for pluviometric climate aggressiveness $(C)$ are shown. Also, climate classifications by Lang and method of hydric balance by Thornthwaitte.were used for characterization of climate. The aim is determination of climate-geographical factors and characterization of the climate characteristics in belt of mountain beech forests on Manjača, aas well as climate impact on growth and development of forest vegetation in the study area.
\end{abstract}

Key words: Manjača, climate elements, climate type.

\section{КАРАКТЕРИСТИКЕ КЛИМЕ У ПОЈАСУ БУКОВИХ ШУМА (Fagetum montanum illyricum Fuk. et Stef. 1958) НА МАҢАЧИ}

Извод: У раду су приказане климатске карактеристике шумског појаса планинске букве на Мањачи у југозападном делу Републике Српске, а на основу климатских података десетогодишњег периода мерења (1971-1980), за ово подручје карактеристичних метеоролошких станица. На основу одређених температурних и

\footnotetext{
${ }^{1}$ Institute of Forestry, 3 Kneza Višeslava, 11030 Belgrade, Serbia
} 
градијената падавина, екстраполацијом су утврђене просечне вредности најважнијих климатских елемената за истраживано подручје. Такође су приказане годишье и месечне вредности климатских елемената, значајних за развој вегетације: температурни и падавински режим, климатско-географске карактеристике - термодромски коефицијент по Kerner-y (KP), индекс суше по De Martonne-y (Is), Furnije-ов коефицијент за плувиометријску агресивност климе (C). За карактерисање климе коришћена је класификација климе по Lang-y и метода хидричног биланса по Thornthwaitte-y. Циљ рада је утврђивање климатскогеографских показатеља и карактерисање обележја климе у појасу букових шума на Мањачи, те утицаја климе на раст и развој шумске вегетације анализираног подручја.

Кључне речи: Мањача, климатски елементи, тип климе.

\section{INTRODUCTION}

Global climate, biological, geological, and chemical processes and natural ecosystems are interconnected, and changes in any of these environmental components can affect humans and other living organisms (Brašanac-Bosanac, Ćirković-Mitrović, 2013). Climate is one of the major environmental factors. It is closely related to other components of the ecosystem in which it has a clearly defined function and importance (Eremija, 2010). Climate conditions determine the occurrence and survival of vegetation in a given area as well as the interrelationships among the constituents of the ecosystem. Climate is closely related to other components of the forest ecosystem and has a significant impact on the growth and development of trees and stands (Kapović, 2011). Climate affects every aspect of a forest, its growing conditions and productivity in a particular area, as well as its regeneration and use (Govedar, 2011). The regimes of rainfall and air temperature are of particular importance to forest ecosystems whose survival and risk depend on a large number of environmental impacts, including climate (Kapović et al., 2013). Some elements of climate affect the intensity of photosynthesis and respiration and other important processes related to the forest stocking. Furthermore, climate has a great impact on the stability of forest ecosystems, with its fluctuations creating favourable conditions for the occurrence of certain phenomena, such as storms or fires. These phenomena can destabilize forest ecosystems in a very short time and often cause their deterioration. Recent research is increasingly focusing on the impact of climate change on forest ecosystems and their resilience to this phenomenon, which varies with their capacity to adapt. To cope with climate change, plant species will need to adapt to changing conditions or migrate to more suitable sites (F A O, 2013 and 2008). Global warming will lead to the extinction of a great number of plant and animal species, biodiversity loss, changing precipitation regimes, reduced availability of water reserves, changes in the frequency and intensity of climate extremes and many other adverse effects on human health (Kadović, Medarević, 2007). Forest ecosystems will change with the global climate change since physiological tolerance limits of species may be exceeded and the rates of biophysical forest processes change. Increasing temperatures cause biological processes, i.e., 
metabolism, respiration, litter decomposition, forest soil mineralization and nitrification to be accelerated, which consequently modifies the biological function of forests (Thompson et al., 2009). The way forests were managed in the past will continue to play a key role in reducing the impact of climate change on forests and the ability of forests to adapt to newly-established climate conditions (Gitay et al., 2001). Due to climate change, Serbia has recently faced frequent and heavy floods, active landslides and erosion, strong wind gusts, frequent and prolonged droughts, with weather extremes affecting both urban and rural areas (Brašanac-Bosanac, 2014).

The study area is located in southwestern Republika Srpska, which is characterized by heterogeneous climate conditions. This area has different climate influences that alternate and combine, which makes it difficult to determine the boundaries between different types of climate (Milosavljević, 1973). From the Sava River in the north to the inland of the Dinarides in the south, the western variant of the Pannonian climate alternates with the humid continental climate and the valley-basin climate, leading to the mountain climate as a variant of the continental climate dominating in the mountains of the southwestern Republika Srpska. The study aimed to determine climate and geographical parameters and characterize the climate in the beech forest belt on Mount Manjača, as well as the impact of climate on the growth and development of the forest vegetation in the study area.

\section{STUDY AREA AND METHOD}

The study area extends from $44^{\circ} 28^{\prime} \mathrm{N}$ to $16^{\circ} 56^{\prime} \mathrm{E}$. It is about $40 \mathrm{~km}$ away from Banja Luka. The mountain stretches in a north-south direction, which deviates from the usual direction of the mountains of the Dinaric Alps. Regarding the geomorphology of the area, the largest part of it is a karst plateau with sinkholes. Regarding the orography, it belongs to the lower mountain zone, and its altitude ranges from 800 to $1150 \mathrm{~m}$. It is mainly covered in forest communities of montane beech (Fagetum montanum illyricum, Fuk. et Stef., 1958).

Data on average monthly and annual air temperatures and precipitation for the period 1971-1980 were used to determine the climate characteristics of the study area. Data on average air temperatures were obtained from the weather stations of "Banja Luka", "Kneževo" and "Jajce", and data on precipitation from "Bočac", "Trijebovo", "Ključ", and "Čađavica". The insufficient number and unfavorable distribution of weather stations have limited the precise definition of the effects of different currents and their spatial delimitation (Stefanović, 1983).

Based on the determined temperature and precipitation gradients, the average values of temperature and precipitation were extrapolated for the study area. The annual, monthly, and growing season values are presented, as well as the annual amplitude of the most important climate elements - air temperature and precipitation. Geoclimatic indicators were also determined. They included the Thermodrome Coefficient after Kerner (KP), De Martonn Aridity Index (Is), and Fournier Index of Pluviometric Climatic Aggressiveness (C). The Lang Climate Classification and the Thornthwaite Water Balance technique were used for the characterization of climate. 


\section{RESEARCH RESULTS AND DISCUSSION}

\section{Air temperature}

The mean annual air temperature in the study area is $6.9^{\circ} \mathrm{C}$ (Table 1$)$. The growing season is characterized by a mean air temperature of $12.2^{\circ} \mathrm{C}$. High air temperatures occur during the summer season when the mean temperature amounts to $15^{\circ} \mathrm{C}$. The mean maximum air temperature in July is $15.8^{\circ} \mathrm{C}$, while the average monthly minimum in January amounts to $-1.6^{\circ} \mathrm{C}$. Besides January, temperatures below zero are recorded in another two winter months, which allows the snow cover to persist longer. The mean annual amplitude of air temperature is $17.4^{\circ} \mathrm{C}$. Temperature inversions are common in lower and sunken areas (depressions). The study area has a typical continental type of the temperature regime - July is the warmest month of the year and January the coldest (K o l i ć, 1986a).

\section{Табела 1. Средюе мјесечне вриједности температуре ваздуха и падавина}

Table 1. Mean monthly air temperature and precipitation values

\begin{tabular}{|c|c|c|c|c|c|c|c|c|c|c|c|c|c|}
\hline $\begin{array}{l}\text { Meceц } \\
\text { Month }\end{array}$ & I & II & III & IV & $\mathbf{V}$ & VI & VII & VIII & IX & $\mathbf{X}$ & XI & XII & $\begin{array}{l}\text { Год. } \\
\text { Year }\end{array}$ \\
\hline $\begin{array}{l}\text { Tемпература }\left({ }^{\circ} \mathbf{C}\right) \\
\text { Temperature }\left({ }^{\circ} \mathbf{C}\right)\end{array}$ & $\begin{array}{c}- \\
1,6\end{array}$ & ${ }^{-}$ & 2,5 & 5,3 & 10,9 & 14,0 & 15,8 & 15,1 & 11,9 & 7,0 & 2,9 & $\begin{array}{c}- \\
0,2\end{array}$ & 6,9 \\
\hline $\begin{array}{l}\text { Падавине }(\mathbf{m m}) \\
\text { Precipitation (mm) }\end{array}$ & 91 & 64 & 61 & 101 & 105 & 102 & 122 & 107 & 109 & 126 & 109 & 90 & 1187 \\
\hline
\end{tabular}

\section{Precipitation}

The annual distribution of precipitation is one of the most important characteristics of the climate of an area. The study area is characterized by high rainfall throughout the year. Combined with the relatively low mean air temperature, it makes the main cause of the humid climate. The annual rainfall average of the study area is $1187 \mathrm{~mm}$. There are two rainfall maxima during the year (Table 1): one in July $(122 \mathrm{~mm})$ and another in October $(126 \mathrm{~mm})$. The minimum rainfall is $61 \mathrm{~mm}$ in March. During the growing season, the area receives an average of $646 \mathrm{~mm}$ of precipitation, which is $54.4 \%$ of the total annual rainfall. Due to heavy rains in July and August, the area receives $229 \mathrm{~mm}$ of precipitation or $19.29 \%$ of the total annual rainfall. Combined with the increase in the mean air temperature, it increases the rate of evapotranspiration. It also causes an increase in the relative air humidity and contributes to the humid climate. Such distribution of rainfall is of great importance for the normal growth and development of trees in the study area. The highest rainfall occurs in autumn, with a relative share of $29 \%$. The major rainfall maximum occurs in October, the lower one in July, while the major rainfall minimum occurs in March and the lower one in February. The relative share of precipitation in the colder part of the year is $21 \%$, while it amounts to $28 \%$ during the summer months. There are no dry months here due to the even distribution of rainfall. The study area has a continental type of precipitation regime - over $50 \%$ of rainfall is in the growing season, although the rainfall maximum occurs in October. 
Climate classification after Lang

Lang's bioclimatic classification is presented based on the annual and seasonal values of the rain factor - RF (Table 2). According to the annual value of the Lang Rainfall Factor, the perhumid climate (RF> 160) prevails in the study area, which allows the forest vegetation to be at its physiological optimum. During the growing season, the climate is humid $(\mathrm{RF}=80-160)$. During the winter months, the climate is hyperhumid, while it is semi-arid in summer and subhumid humid in autumn.

Табела 2. Вриједности Lang-овог кишног фактора

Table 2. Lang Rain Factor values

\begin{tabular}{|l|r|}
\hline & KF/RF \\
\hline Година - Year & 172.0 \\
\hline Вегетациони период - Growing season & 105.9 \\
\hline Пролеће - Spring & 57.1 \\
\hline Лето - Summer & 29.5 \\
\hline Јесен - Autumn & 63.1 \\
\hline Зима - Winter & - \\
\hline
\end{tabular}

Thornthwaite Water Balance

The soil water balance, i.e. the ratio of surplus, deficiency, and reserves of water in the soil, is of particular importance for the survival, growth, and development of plants. Plants have different water requirements, which depend on the characteristics of plant species. The fulfillment of these requirements is determined by environmental conditions, primarily energy and temperature conditions and rainfall totals. This method uses rainfall and air temperature values, which are adjusted depending on the daylight length and the latitude of the station. The results of the Water Balance calculation are shown in Table 3 and Graph 1.

Табела 3. Основни климатски показатељи за подручје истраживања по Thornthwaite-y

Table 3. Main climate indicators for the study area after Thorntwaite

\begin{tabular}{|c|c|c|c|c|c|c|c|c|}
\hline $\begin{array}{l}\text { Meceu } \\
\text { Month }\end{array}$ & $\begin{array}{l}\text { T }\left({ }^{\circ} \mathbf{C}\right) \\
\text { T }\left({ }^{\circ} \mathbf{C}\right) \\
\end{array}$ & и & \begin{tabular}{|l|} 
(IET) $\mathrm{mm}$ \\
(PET) $\mathrm{mm}$
\end{tabular} & $\begin{array}{l}\text { ПET }(\mathbf{m m}) \\
\text { PET }(\mathrm{mm})\end{array}$ & $\begin{array}{l}\Pi(\mathbf{m m}) \\
\mathbf{P}(\mathbf{m m})\end{array}$ & $\begin{array}{c}\text { CET }(\mathbf{m m}) \\
\text { AET }(\mathbf{m m})\end{array}$ & $\begin{array}{l}M(\mathbf{m m}) \\
M(\mathbf{m m})\end{array}$ & $\begin{array}{l}\mathbf{V}(\mathbf{m m}) \\
\mathbf{V}(\mathbf{m m})\end{array}$ \\
\hline I & -1.6 & 0.0 & $\begin{array}{l}0.0 \\
\end{array}$ & 0.0 & 91 & 0.0 & \begin{tabular}{|l|}
0.0 \\
\end{tabular} & 91.0 \\
\hline II & -0.6 & 0.0 & 0.0 & 0.0 & 64 & 0.0 & 0.0 & 64.0 \\
\hline III & 2.5 & 0.4 & 15.3 & 16.2 & 61 & 15.7 & 0.4 & 45.3 \\
\hline IV & 5.3 & 1.0 & 28.7 & 32.4 & 101 & 30.7 & 1.8 & 70.4 \\
\hline $\mathrm{V}$ & 10.9 & 3.3 & 52.3 & 68.6 & 105 & 60.8 & 7.8 & 44.3 \\
\hline VI & 14.0 & 4.8 & 64.4 & 83.0 & 102 & 71.6 & 11.5 & 30.5 \\
\hline VII & 15.8 & 5.7 & 71.2 & 95.7 & 122 & 80.4 & 15.3 & 41.6 \\
\hline VIII & 15.1 & 5.3 & 68.6 & 85.0 & 107 & 73.0 & 12.1 & 34.0 \\
\hline IX & 11.9 & 3.7 & 56.2 & 58.5 & 109 & 52.8 & 5.7 & 56.2 \\
\hline $\mathrm{X}$ & 7.0 & 1.7 & 36.1 & 35.5 & 126 & 33.4 & 2.1 & 92.6 \\
\hline $\mathrm{XI}$ & 2.9 & 0.4 & 17.3 & 13.9 & 109 & 13.6 & 0.3 & 95.4 \\
\hline XII & -0.2 & 0.0 & 0.0 & 0.0 & 90 & 0.0 & 0.0 & 90.0 \\
\hline God.-Yearly & 6.9 & 26.3 & 410.1 & 488.8 & 1187 & 432.0 & 57.0 & 755.3 \\
\hline IV-IX & 12.2 & 23.8 & & 423.2 & 646 & 369.3 & 54.2 & 277.0 \\
\hline
\end{tabular}


Potential evapotranspiration, i.e., the amount of water that evaporates under given energy and temperature conditions is greater than the actual evapotranspiration except in the cold, winter period when the PET and AET values are approximately equal. It amounts to $488.8 \mathrm{~mm}$ or $41 \%$ of the total rainfall.

Apart from the energy-temperature conditions, actual evapotranspiration depends on the amount of precipitation and amounts to $88 \%$ of the potential (maximum possible). Graph 1 shows that the amount of moisture that can potentially evaporate is greater than the amount of water that actually evapotranspires. During the year, the rainfall in the study area is higher than the AET, so the soil generally has favorable moisture.

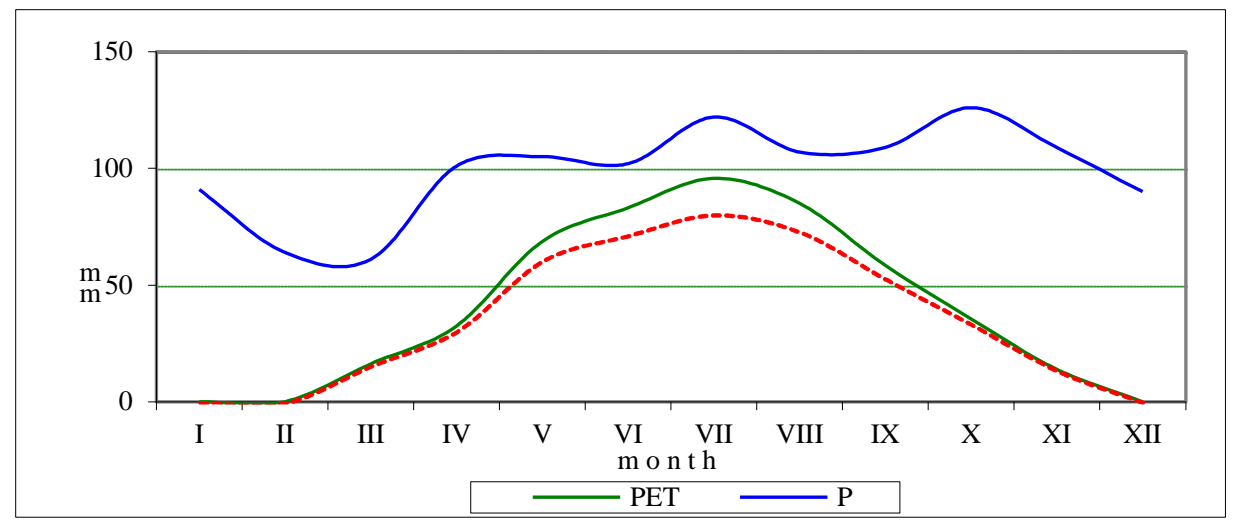

Графикон 1. Климадијаграм по Thornthwaite-y Graph 1. Thornthwaite Climate Diagram

There is a deficiency of water in the soil during the summer months, but it is not very pronounced. The highest average value of water deficiency occurs in July. The area is mostly characterized by the constant presence of moisture surplus in the soil. A more pronounced surplus is recorded in the colder part of the year from November to April, accounting for 38\% of the annual rainfall. The ratio of the surplus to deficiency of water in the soil shows that forest trees in the study area have sufficient moisture for their growth and development.

The general climate index was calculated based on the values of the Aridity Index - Ia and the Humidity Index - Ih (Table 4):

Tabela 4. Indeksi aridnosti, humidnosti i klimatski indeks

Table 4. Aridity, Humidity and Climate Indices

\begin{tabular}{|c|c|c|}
\hline $\begin{array}{c}\text { Индекси } \\
\text { Index }\end{array}$ & $\begin{array}{c}\text { Година } \\
\text { Year }\end{array}$ & $\begin{array}{c}\text { Вег. период } \\
\text { Growing season }\end{array}$ \\
\hline Ia & 11.65 & 12.78 \\
\hline Ih & 154.54 & 65.43 \\
\hline Ik & 147.55 & 57.77 \\
\hline
\end{tabular}

According to the values of the annual climate index in the study area, it is dominated by the perhumid climate - A, while the moderately humid - B2 climate prevails during the growing season. 
Geoclimatic characteristics

The interelatedness between the geographical location of a site and the elements of climate are called geoclimatic characteristics (K o l i ć, 1988). The values of the most important geoclimatic characteristics are shown in Table 5.

The degree of climate continentality determined by the Kerner Thermodromic Coefficient (KP\%) expresses the degree of the landmass influence. According to this element, the study area has a humid continental - mountain climate.

The type of runoff determined using the De Martonne Aridity Index (Is) shows that there is a pronounced exoreism in the study area, i.e., the water runoff is abundant, which means that the study area is highly forested.

The pluviometric vulnerability determined by the Fournier Index of Pluviometric Climatic Aggressiveness (C), i.e., the vulnerability of the area to pluvial erosion (caused by the impact of raindrops) point to moderate vulnerability.

Табела 5. Климатско-географске карактеристике

Table 5. Geoclimatic characteristics

\begin{tabular}{|l|l|l|l|l|l|}
\hline \multicolumn{2}{|c|}{$\begin{array}{l}\text { Континенталност подручја } \\
\text { Continentality of the region }\end{array}$} & \multicolumn{2}{|c|}{$\begin{array}{l}\text { Индекс суше по De Martonn-y } \\
\text { De Martonn Aridity Index }\end{array}$} & \multicolumn{2}{|c|}{$\begin{array}{c}\text { Плувиометријска } \\
\text { угроженост } \\
\text { Pluviometric vulnerability }\end{array}$} \\
\hline $\begin{array}{l}\text { КП \% } \\
\text { КР \% }\end{array}$ & $\begin{array}{l}\text { Климатски тип } \\
\text { Сlimate tyре }\end{array}$ & $\begin{array}{l}\text { ИС } \\
\text { IS }\end{array}$ & $\begin{array}{l}\text { Отицање воде } \\
\text { Runoff }\end{array}$ & $\begin{array}{l}\text { С } \\
\text { Пип угрожености } \\
\text { Vulnerability type }\end{array}$ \\
\hline $\begin{array}{l}\text { Блага континентална } \\
\text { - планинска } \\
\text { Humid continental } \\
\text { - mountain }\end{array}$ & 70.2 & $\begin{array}{l}\text { Обилно } \\
\text { Abundant }\end{array}$ & 13.4 & $\begin{array}{l}\text { Oсредња } \\
\text { Moderate }\end{array}$ \\
\hline
\end{tabular}

Comparative climate indicators

Table 6 compares the research results on the mean precipitation $(\mathrm{P})$, average maximum and minimum air temperature ( $T_{\max }$ and $\left.T_{\min }\right)$, the amplitude of temperature fluctuation (A) with the results of previous studies (Milosavljević, 1973). The mountain climate prevails in the study area.

Табела 6. Упоредни климатски показатељи подручја са резултатима Милосављевића (1973)

Table 6. Climate indicators of the region compared with the results of Milosavljević (1973)

\begin{tabular}{|l|c|c|c|c|c|}
\hline $\begin{array}{l}\text { Тип климе } \\
\text { Climate type }\end{array}$ & $\begin{array}{l}\mathbf{\Pi}(\mathbf{m m}) \\
\mathbf{P}(\mathbf{m m})\end{array}$ & $\begin{array}{c}\mathbf{T} \text { год }\left({ }^{\circ} \mathbf{C}\right) \\
\mathbf{T y e a r}\left({ }^{\circ} \mathbf{C}\right)\end{array}$ & $\begin{array}{c}\mathbf{T}_{\text {мин }}\left({ }^{\circ} \mathbf{C}\right) \\
\mathbf{T}_{\min }\left({ }^{\circ} \mathbf{C}\right)\end{array}$ & $\begin{array}{c}\mathbf{T}_{\text {мах }}\left({ }^{\circ} \mathbf{C}\right) \\
\mathbf{T}_{\max }\left({ }^{\circ} \mathbf{C}\right)\end{array}$ & $\begin{array}{c}\mathbf{A}\left({ }^{\circ} \mathbf{C}\right) \\
\mathbf{A}\left({ }^{\circ} \mathbf{C}\right)\end{array}$ \\
\hline $\begin{array}{l}\text { Умерено-континентална } \\
\text { Нumid continental }\end{array}$ & $700-1950$ & 10,2 & $-0,3-3,0$ & $>20,0$ & 20,0 \\
\hline $\begin{array}{l}\text { Долинско-котлинска } \\
\text { Valley-basin }\end{array}$ & $750-1000$ & $8,0-10,0$ & $-3,0$ & $18,0-20,0$ & $20,0-21,0$ \\
\hline $\begin{array}{l}\text { Планинска } \\
\text { Моuntain }\end{array}$ & $1200-1500$ & $<8,0$ & $<-3,0$ & $<18,0$ & $18,0-19,0$ \\
\hline $\begin{array}{l}\text { Подручје истраживања } \\
\text { Research area }\end{array}$ & 1187 & 6,9 & $-2,6$ & 16,3 & 18,9 \\
\hline
\end{tabular}




\section{CONCLUSIONS}

The article presents the climate characteristics in the forests of the montane beech of Illyrian region (Fagetum montanum illyricum Fuk. et Stef., 1958) in the Mount Manjača area in southwestern Republika Srpska.

The general characteristics of the temperature and precipitation regime of the analyzed forest belt are as follows: the mean annual air temperature is $6.9^{\circ} \mathrm{C}$ and the mean annual precipitation is $1187 \mathrm{~mm}$. There are no dry months during the year because rainfall is evenly distributed (over $50 \%$ of precipitation is in the growing season) so that the continental type of temperature and precipitation regime prevails.

Lang`s bioclimatic classification shows that the climate is humid during the growing and hyperhumid in winter. In summer, it is semi-arid and subhumid humid in autumn.

The water balance shows that during the year the potential evapotranspiration is greater than the actual one except in the cold winter period when their values are approximately equal. The lack of water in the soil occurs during the summer months but is not very pronounced. According to general and geoclimatic indicators, it can be concluded that the study area is characterized by a perhumid, humid continental climate - mountain type, with pronounced exoreism, moderate pluviometric vulnerability, which defines it as extremely forested areas with favourable conditions for the growth and development of forest trees.

Acknowledgments: The paper was realized as a part of project "The development of technological processes in forestry in order to realize the optimal forest cover " (TR31070), financed by the Ministry of Education, Science and Tecnological Development of the Republic of Serbia (2011-2019).

\section{REFERENCES}

Brašanac-Bosanac, Lj. (2014): The climate change - strategies and legislation in Serbia. Sustainable Forestry Tom 69 - 70, Institute of Forestry, Belgrade, pp. $7-16$.

Brašanac-Bosanac, Lj., Ćirković-Mitrović, T. (2013): Air temperature changes in Serbia in period $1949-2010$ in view of global climate changes, Sustainable Forestry Tom $67-68$, Institute of Forestry, Belgrade, pp. 7 - 14.

Govedar, Z. (2011): Silviculture, ecological basics, University of Banja Luka, Faculty of Forestry.

Gitay, H., Brown, S., Easterling, W., and Jallow, B. 2001. Ecosystems and their goods and services. In: Climate Change 2001: Impacts, adaptation, and vulnerability [McCarthy, J. J., Canziani, O.F., Leary, N.A., Dokken, D.J., and White, K.S. (eds)]. Contribution of Working Group II to the Second Assessment Report of the Intergovernmental Panel on Climate Change Cambridge University Press, Cambridge, UK. pp. 235 - 341.

Eremija, C. (2010): Climate characteristics of the altitudinal belts of Lisina Mountain near Mrkonjić Grad. Forestry, No. 1 -2, Association of Forestry Engineers and Technicians of Serbia, Belgrade, p. $107-116$. 
Kadović, R., Medarević, M. (2007): Forests and climate change. Proceedings, Ministry of Agriculture, Forestry and Water Management - Forest Directorate and University of Belgrade - Faculty of Forestry.

Kapović, M. (2011): Climate Characteristics of Mount Javor in Republika Srpska, Bulletin of the Faculty of Forestry, University of Banja Luka, 2011, No.14, pp. 29 - 41.

Kapović-Solomun, M., Čomić, D., Lazović, N. (2013): Trend Analysis of the Changes in Climate Types in the Foča Region, Bulletin of the Faculty of Forestry, University of Banja Luka, 2013, No. 19, pp. $07-22$.

Kolić, B. (1986a): Macroclimatic area classification of northeastern Serbia, Manuscript, Faculty of Forestry, Belgrade

Kolić, B. (1988): Forest Ecoclimatology, Naučna knjiga, Belgrade

Milosavljević, R. (1973): Climate of Bosnia and Herzegovina, Ph.D. thesis, Sarajevo

Stefanovic, V., Beus, V., Burlica, C., Dizdarević, H., Vukorep, I. (1983): Ecological Vegetation Area Classification of Bosnia and Herzegovina, Special Issues of the Faculty of Forestry in Sarajevo, No. 17, Sarajevo

Thompson, I., Mackey, B., McNulty, S., Mosseler, A. (2009). Forest Resilience, Biodiversity, and Climate Change. A synthesis of the biodiversity/resilience/stability relationship in forest ecosystems. Secretariat of the Convention on Biological Diversity, Montreal. Technical Series no. 43, 67 pages.

FAO (2008): Climate change impacts on forest health, Forest Health and Biosecurity Working Papers FBS/34E, Forestry Department, Food and Agriculture Organization of the United Nations, FAO, Rome, Italy.

FAO (2013): Climate change guidelines for forest managers, FAO Forestry Paper No. 172. Rome, Food and Agriculture Organization of the United Nations.

\section{CLIMATE CHARACTERISTICS OF THE MONTANE BEECH FOREST BELT (Fagetum montanum illyricum Fuk. et Stef. 1958) ON MOUNT MANJAČA}

Saša EREMIJA, Ljiljana BRA ̌̌ANAC-BOSANAC, Tatjana ĆIRKOVIĆ-MITROVIĆ, Snežana STAJIĆ

\section{Summary}

The article presents the climate characteristics in the forests of the montane beech of Illyrian region (Fagetum montanum illyricum, Fuk. et Stef., 1958) in the Mount Manjača area in southwestern Republika Srpska. The general characteristics of the temperature and precipitation regime of the analyzed forest belt are as follows: the mean annual air temperature is $6.9^{\circ} \mathrm{C}$ and the mean annual precipitation is $1187 \mathrm{~mm}$. There are no dry months during the year because rainfall is evenly distributed (over $50 \%$ of precipitation is in the growing season) so that the continental type of temperature and precipitation regime prevails.

Bioclimatic classification based on Lang's rain factor shows that the climate is humid during the growing and hyperhumid in winter. In summer, it is semi-arid and subhumid humid in autumn. 
The water balance shows that the potential evapotranspiration is greater than the actual one except in the cold winter period when their values are approximately equal. The lack of water in the soil occurs during the summer months but is not very pronounced.General and geoclimatic indicators, shows that research area is characterized with perhumid, mild-continental climate - mountainous type, with expressed egzoreism and average pluviometric vulnerability. This is area with favorable conditions for growth and development of beech forests. 